Thorax, 1980, 35, 160

\title{
Severe asthma after inadvertent ingestion of oxprenolol
}

\author{
I P WILLIAMS AND F J C MILLARD
}

From the Department of Thoracic Medicine, St James' Hospital, London

We report a case in which the accidental ingestion of $80 \mathrm{mg}$ of oxprenolol resulted in a respiratory-cardiac arrest. The report draws attention to the dangers of $\beta$ blockers in asthmatics, and to the rapidity with which serious sequaelae may follow their administration.

\section{Case report}

The patient, a 36-year-old Caucasian woman, had suffered from asthma for 21 years. Her symptoms were relatively mild. She had not needed systemic corticosteroids, nor time off work. She was allergic to a wide variety of allergens and had exercise-induced asthma. Medication for many years had consisted of salbutamol by inhalation. Some months before this episode she had moved house and had noticed a worsening of dyspnoea which resulted in her starting inhaled beclomethasone $400 \mu \mathrm{g}$ per day in addition to full doses of salbutamol. Her peak expiratory flow rate was never found to be below 250 litres per minute even when symptomatic.

She was prescribed chlorpheniramine and collected it from the pharmacist together with oxprenolol that had been prescribed for a friend. She took $80 \mathrm{mg}$ of oxprenolol orally in error. Increasing wheeze started about an hour after ingestion, and this worsened so that after two hours she was unable to walk. She deteriorated rapidly thereafter having in sequence, a convulsion, a respiratory arrest, and ventricular fibrillation. Treatment consisted of intermittent positive pressure ventilation, intravenous aminophylline, a salbutamol infusion, and intravenous hydrocortisone (figure). The inspiratory pressure required on a Cape Bristol ventilator was initially very high (70 centimetres of water), within three hours pressure had fallen to 32, and within eight hours to 26 . Ventilation was continued for 11 hours. She was then taken off the ventilator, and remained well perfused with no residual evidence of bronchospasm.

\section{Discussion}

The most important feature of this case history is the rapidity of onset of life-threatening bronchospasm after $80 \mathrm{mg}$ of oxprenolol, a relatively small dose in terms of therapy for most cardiovascular problems. The

Address for reprint requests: Dr IP Williams, Department of Thoracic Medicine, St James' Hospital, Sarsfield Road, Balham, London. drug is absorbed rapidly from the alimentary tract peak concentrations occurring in the blood within onet to three hours, ${ }^{1}$ and has a half-life of about fou hours. The symptoms followed the predicted plasmen concentrations closely. The intrinsic sympathomimetidu activity of oxprenolol, which is thought to offer som $\vec{B}$ protection against bronchospasm, was insufficient in this instance. Asthmatics are particularly sensitive to $\beta$ blockers and this patient clearly had no sympathetie reserves as she was already taking salbutamol ang beclomethasone.

The degree of sensitivity in an otherwise welt controlled asthmatic patient is a reminder of the extreme caution needed in giving $\beta$ blockers to any susceptible patient. It might be advisable for bottleso containing $\beta$-blocking drugs to be labelled as dangerous to asthmatics, as the possibility of sucf widely prescribed medicines being taken by acciden or for anxiety must be increasing.
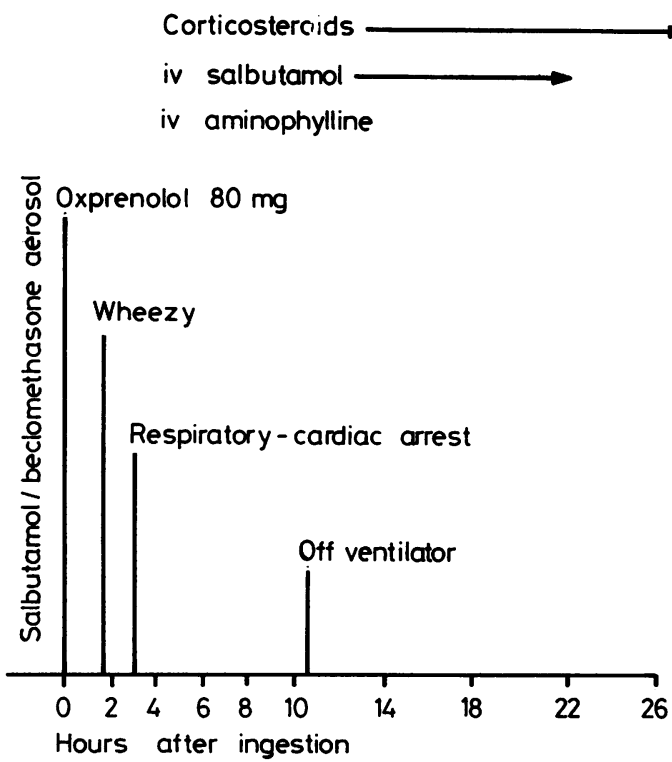

Figure Time course after ingestion of oxprenolol.

\section{Reference}

1 McDevitt DG, Shanks RG, Prichard BNC. The clinical pharmacology of beta adrenergic blocking drugs. J R Coll Physicians 1976; 11:21-34. 